6. Notice of Two Localities for Remarkable Gravel Banks or Kaims, and Boulders, in the West of Scotland, in Supplement of the Boulder Committee's Tenth Report. By David Milne Home, LL.D. (Plates XI. to XIII.)

\title{
I. LOCHABER.
}

About eight or ten years ago, when in Lochaber, studying the "Parallel Roads" problem, I became acquainted with a district in the valley of the River Spean, which presented the phenomena of gravel banks or kaims, and boulders, on a larger scale than I had ever before or have since met with.

The lowest of the "Parallel Roads," marked No. IV. on the Ordnance Survey Maps, traverses this district; and whilst tracing the direction of the "Road," as it crosses the lines of these banks and boulders, I was greatly puzzled to account for them, and still more for the lines in which they had been deposited. I took notes, and made rough sketches of both at the time, hoping that I might have an opportunity of a more special investigation. A failure of bodily strength supervened, which deprived me of the opportunity; but as I deem the district well worthy of the attention of geologists, on account of the light it seems to throw on questions of much interest, I propose to give a short account of the facts observed on the occasions referred to, taken from notes and sketches made at the time.

Much assistance ean now be obtained for an examination of the district from the Ordnance Survey Maps. At the instance of several scientific Societies, Her Majesty's Government gave authority to the late Sir Henry James, then Director-General of the Survey, to have special maps made, to indicate the "Parallel Roads" in the different Lochaber valleys; and latterly, at the joint request of the Edinburgh Royal and Edinburgh Geological 
Societies, he caured a map (on the 6-inch scale) to be executed of the particular districts in the Spean valley, to which I am about to refer.

This district is in that part of the valley where the River Spean, flowing from Loch Laggan, is joined by a smaller stream from Loch Treig,

The Outline Map A (Plate XI.) gives a general idea of the position of the gravel banks, with reference to Loch Treig and the adjoining Rivers Spean and Treig. The dark dotted line indicates shelf IV., being the lowest beach of the lake which stood at a height of about 855 feet above the searlevel. The dark shaded line, surrounding the valley, shows generally the position of the adjoining hills, at a level above the sea of from 1300 to 1500 feet.

I had my attention first drawn to these banks and boulders when walking along the line of shelf IV, near the mouth of Loch Treig. On looking up at the hill slope situated to the south of this loch, I noticed several projecting lines of terraces, at much higher levels than shelf IV., and at first thought that they might represent some of the shelves of the higher lakes, which had been recognised in ather Lochaber glens, but not in this one.

I thereupon ascended the hill, and, an doing so, obtained a general view of the low grounds, and of the remarkable assemblage there of kaims and boulders. I at once saw that many of both formed lines, in some cases rectilineal, but also and even more frequently curvilineal, the inner curves facing the north, $i_{0} e_{0}$, down Glen Spean, (See A on Sketch Map, Plate XI.)

The first terrace on the hill slope which I reached was (by aneroid) at a height of 1120 feet above sea-level, The terrace presented a level surface from 40 to 50 feet wide, abutting against the hill, and was composed of water-borne gravel. Two great boulders lay on this terrace, about 200 yards apart.

From this terrace I climbed to another, at a height of 1165 feet above sea-level; on it were three large boulders.

There was still another terrace, and its height above the sea I found to be 1175 feet.

Again a higher terrace was reashed, 1480 feet above the sea, somewhat broader than the others, and having a considerable number of boulders on it. 
I did not observe any torraces at a higher level; but I saw that there were many boulders on the slope of the hill above, some of large size.

With the view of proceeding next to the low grounds, where the extended lines of kaims and boulders were seen to be situated, I walked south along the highest of the above terraces, and observed that it gradually ceased to touch or abut with a flat surface on the hill, and that it became separated from the hill by a narrow trough, as if the detritus next the hill had been scoured out by the action of water currents, or of rain descending on it from the slope of the hill. The terrace at length became so narrow as to become a bank or ridge, the outer flank of which was, of course; much higher than the flank next the hill.

The upper surface of the terrace now ceased to be horizontal $1_{j}$ and sloped down towards the $S_{1} E$. As I proceeded, I observed, on my right hand, some rocks much smoothed, at a height of from 1500 to 1600 feet.

A little further south, I came to a profecting rocky corner of the hill, named Craig Dhubh, indicated on the one-inch Ordnance Map by the sudden bending of the contour lines towards the S.W. The surfaces of the rocks there were seen to have been greatly smoothed (apparently from the north), whilst immense masses of rock were lying at the foot of the crag; It was only at this corner of the hill that any smoothing of these masses existed. Rocks continued in a S.W. direction without any such features. The agent which had produced these effects had, at this point, apparently slanted off towards the S.E.

Before descending further, I looked with my glass across the valley towards the hills on the east, and deseried there several lines of terrace on the south projecting shoulder of Craig Dhu and Connichte, and also on some high ground near the Rough Burn (Sketch Map B, Plate XI.). These I decided on visiting, after inspection of the low grounds immediately below me.

In my way towards the low grounds A, I walked along a kaim or gravel bank, whose course followed a direction about E.S.E., and sloped downwards, with steep sides from 20 to 30 feet high. I observed that there were also many boulders on the low grounds, some of them forming lines or trainées. 
The district occupied by these kaims was tolerably flat, and about $2 \frac{1}{2}$ miles wide (in an east and west direction) across the general course of the River Spean.

There were several lines of kaims all approximately parallel, and presenting a slight cyrvature; - the inner curves facing the north, or down the valley of the Spean.

At one place there was an interruption in the continuous line of the northernmost bank, as if it had been broken through by some agent from the north; and I took a rough sketch of it on the spot, being fig. 1 on Plate XIII.

At $\mathrm{A}$, the kaim $\mathrm{BC}$ ceases for about twenty yards; and between this "break," and the other bank DE, there is a heap of boulders.

The highest and thickest of the two banks is $\mathrm{BAC}$, and on it the greatest number of boulders are accumulated.

On the low ground to the north of these kaims there are many grey granite boulders of various sizes scattered about, mostly angular.

There two knobs about twelve or eighteen feet high attracted my attention, in consequence of there being boulders on their tops. One of the knobs was of detritus; the other of rock, sloping down steeply on all sides, except the east.

In each case the diameter of the flat surface at the top was about six or seven yards, and there were five or six boulders on each;-most of the boulders were on the sides facing the N. and N.W.

In several places, and especially at the north base of the most northern kaim, BAC, there were boulders piled over one another. On studying these, I became impressed with the belief that the uppermost boulder, being the last which came, should show the quarter from which it must have come, to get into its position.

Diagrams on Plate XII. represent these cases, showing that the boulders had come from some northerly point.*

There was one place where rocks in situ of grey granite were found smoothed; the smoothed face being towards the north, and a boulder lying on that side. The farther progress of the boulder to the south had been apparently obstructed by the smoothed rocks. This case is shown by fig. 1, Plate XII.

* Explanations of the Plates are appended to this notice. 
On several occasions subsequently, I examined the banks and boulders, occupying the district on the east side of the River Spean, and situated to the north of the spot on the Ordnance Map called "Rough Burn." (See B on the Sketch Map, Plate XI.)

I found several, and especially two remarkable kaims, running in a somewhat different direction from those on the west side of the valley, viz., towards south, and curving like the rest, 一 with the inner curve facing the west. I walked along the top of the two highest kaims. Their sides were steep, and reached in some spots to a height of 30 to 40 feet, with many boulders on them.

These kaims occupy portions of the hill, which slopes up towards the north, from about 1100 to 1245 feet above sea-level:

Standing on these kaims, I could descry Loch Treig, which by compass bears from them about S.S.W. The level of the loch is represented in the Ordnance Map as 784 feet above sea-level.

Some of the boulders, on the level ground in several parts of the valley, form trainées, more or less parallel with the lines of the kaims.

The following are the dimensions of some of the boulders on the east side of the valley :-

One measured in girth 19 paces, and in height 5 feet

Another measured $12 \times 3 \times 2$ feet, with longer axis $\mathrm{S} . \mathrm{W}$.

$$
\text { " } 15 \times 10 \times 4 \text { feet }_{s}, ",
$$

It is proper to add; that shelf IV, before referred to as the beach line of the lowest lake, is visibly impressed on the gravel banks, on both sides of the valley; and they are so indicated on the Ordnance Map.

These kaims, therefore; belong to a period in history more ancient than the Lochaber lakes.

\section{Theory.}

With regard to the origin of these banks and boulders, there can be little or no doubt that the materials of the banks, consisting chiefly of well-rounded pebbles and blocks, and in some cases of sand, in beds partially stratified, must be due, in some way, to the agency of water, with deep and powerful currents. 
The detritus had assuredly not fallen from the adjoining hills, by the natural decay of the rocks composing them.

The late Dr Macculloch, who was eminent as mineralogist, geologist, and chemist, visited Lochaber, to seek for data to enable him to try and solve the problem of the parallel roads; and wrote an elaborate paper on the subject, which was published in the Transactions of the London Geological Society for 1817, vol. iv.

$\mathrm{He}$ particularly studied the nature of the gravelly materials lying on the surface of the country, and he found that these were of two descriptions. He observed that the debris of the rocks were angular in shape:-The other class he called " transported alluvium of pebbles, sand, and gravel;" and these, he observed, generally differed in mineralogical composition from the rocks of the hills on which they lay. "The alluvium (he says) was not thus rounded by the action of the water which produced the lines (i.e., the parallel roads). We must suppose that this rounded alluvium had been, by previous causes, accumulated. If this took place from the action of water (and to what other cause can we assign it ?), it must belong to an epoch prior to the deposits of sharp matter in the upper parts" (page 330).

Again he says :- " The conoidal hillocks, occurring between Glen Fintec and Glen Glastrie, consist of deposits of fine sand, clay, and rolled stones of different sizes,-disposed in a manner irregularly stratified, and in a direction more or less horizontal. The terraces and hillocks, which occupy positions much inferior to these, all the way along the course of the Spean, are of the same materials" (page 339).

The hillocks in Glens Fintec and Glastrie, here mentioned as examples of "transported allavium," occupy positions exceeding 1200 feet above the sea, and are (Macculloch says) the same kind of deposits as those along the course of the Spean, referring, no doubt, to the kaims described in this paper.

Examples of these detrital deposits occur in all the Lochaber glens. In Glen Roy and its lateral valleys, there are cliffs of boulder clay, exceeding 200 feet in depth. Along the course of the Spean at Murlaggan, on the east bank, there are cliffs of sand, partially stratified horizontally, above 80 feet deep; and on the west side, 
at Alt-na-Bruach, there are cliffs of mixed sand and gravel, equally deep, all more or less stratified.

The River Treig, near its exit from the loch, has cut through banks of gravel, also stratified, exceeding 70 feet in depth.

It may be added that any one passing through the Caledonian Canal, near Banavie, may see great gashes on the Moy Hills to the north, occurring in enormous beds of white sand, at a height of 2000 feet above sea-level.

Mr Jamieson of Ellon examined the whole of this district carefully, and mentions that at the outlet of Loch Treig he found "strix running horizontally along the face of the rocks up to 2000 feet;" and he adds, "not that I affirm even this to be their upper limit." $\mathrm{He}$ mentions similar features, even as high as 3055 feet above the sea, "which (he says) raise a suspicion that some denuding agent has flowed over it at a period geologically recent." (Lond. Geol. Soc. Journal, 26th Feb. 1862, p. 172.)

In these circumstances, it seems impossible to doubt that the sea has flowed over the whole of this district, and in such a way as to bring detritus of sand, mud, gravel, and boulders, and deposit them alike on hills and in valleys. The detritus which forms the keims in the Spean valley, which I have been deseribing, must therefore almost certainly have been brought and deposited there by oceanic agency.

The gravel banks or kaims of the Spean valley are not unexampled in many other parts of Scotland. In Linlithgowshire a gravel bank, with steep sides, runs from Polmont eastward, nearly two miles continuously, with occasional bends, and is now cut across at several points by small rivers. In Haddingtonshire a similar east and west kaim runs for about a quarter of a mile. In Nairnshire there is a similar kaim, traceable for a greater distance. In Berwickshire, on Greenlaw Muir, at a height of about 1000 feet above the sea, there is a gravel bank, high and steep, about three miles in length, presenting several considerable bends in its course, and cut across by two small streams.

In consulting the Admiralty Maps, which show the forms of submarine sandbanks, I find many examples running for more than a mile continuously, and, in one case, a bank curved into almost a semicircle. Off the mouth of the Thames, where the tidal currents are strong, there are several such cases. 
When Scotland was submerged, the currents in this region would probably be rapid, looking to the relative positions of the hills and valleys.

If the question be thought of any importance, it may be noticed on the Map, Plate XI., that this part of the Spean valley is so surrounded by hills, as to be an area well fitted for the reception and detention of detritus, its diameter being about three miles:

Moreover, it is worthy of notice that the valley in which this area occurs is contracted at its north end, so that if a current flowed at that end, towards the Spean valley, it would enter the valley with considerable velocity, and in virtue of the way in which it is surrounded by hills; it might acquire a circular motion, producing whirlpools or eddies.

It will be found, on consulting the contour lines of the one-inch Ordnance Map, that whilst the space where the kaims and boulders are situated is (between the contour lines of 1250 feet) three miles across, the breadth of the valley to the north, between the same contour lines, is only $1 \frac{1}{2}$ miles (see Sketch Map, Plate XI.). To the north of this gorge there is open country, and at a low level; so that if the country was then submerged there would be opportunity for a large body of water flowing through the gorge towards the south.

Now it is allowable here to observe that there are strong reasons for believing that when Scotland was submerged a powerful current, with floating ice from some north-westerly point, did prevail here, as probably elsewhere in Scotland. A few of the facts bearing on this point may be mentioned.

(1) The most important of the lateral glens joining Glen Spean is Glen Roy, which runs for about 16 miles towards its head or col in a S.E. direction. I extract the following paragraph from the notes taken by me when I visited this glen in 1846 :- "Visited head of Glen Roy. In upper Glen Roy it is interesting to observe how uniformly the smoothed surfaces of rocks are to the west, and their rough faces to the east."

As this is a point of some importance, I confirm my own observation by a quotation from the Memoir of Mr Jamieson of Ellon, who, with a view to the "Parallel Roads" problem, made an elaborate survey of all the Lochaber glens. Near the top of Glen Roy, he 
says (Lond. Geol. Society's Proceedings, vol. xviii. p. 296)-“I was not a little surprised to find that the ice had come from the S.W., i.e., up Glen Roy..... . The strata had been so blunted and rubbed on their $S W$. exposures as to show plainly that the movement came from that quarter; and high up on the brow of the adjoining hill I saw several very large blocks and boulders that appeared to have been shifted or moved some distance . . . . by glacial action."

Mr Jamieson stggests that this rubbing of the rocks, on their S.W. exposures, was due to "glacial action." If ice moved up the glen it could not have been glacier, but floating ice.

(2) In Glen Gluoy Valley, adjoining Glen Roy, and opening like it towards the west, similar proofs exist of a movement up the glen, from the westward (see "Memoir on Parullel Roads," Edinburgh Royal Society Transactions, vol, xxvii. p. 638).*

(3) Craig Dhu, a hill situated on the east side of the gorge before mentioned, reaches to a height of 2100 feet, and presents several spots near the summit on its N.W. side, where the edges of the strata show smoothing from the north. The boulders on the hill are also chiefly on the north slopes.

(4) Ben Chlinaig is a hill on the west side of the gorge, reaching to a height of 2545 feet. Mr Jolly of Inverness informed me that on its eastern slope he found rock striations at a height of 1840 feet, running N.W. and S.E.

(5) In the gorge itself, near its lowest level, some of the rocks present large smoothings facing the north, and grooves of great length, evidently caused by violent and severe friction of heavy bodies which had moved over the rocks.

(6) Then on the N.W. shoulder of Ben Nevis, at the mouth of

* As these pages were being printed, I received from my old and esteemed friend, Colin Livingston of Fort-William, a letter (dated 23rd September 1884) narrating an excursion he had a few days previously made to Glen Gluoy, and mentioning that at a height of about 1750 feet above the sea he had found several granite boulders on the side of a hill facing the west, and lying on quartzite rocks, which were smooth on their west sides and rough on their east sides. He adds that three of these boulders formed a line or trainée uf abou a 100 to 120 yards. He became satisfied, from these facts, that the boulders had come up the glen from the westward, and not down the glen, as he had previously supposed. The nearest locality for granite rocks, known to him, is "Meallan-Suidhe," sitnated some miles to the westward. 
a glen called Corry $N^{\prime}$ Eoin, I found, at two different spots, rocks so striated as to show that the striating agent had moved from N.N.W., i.e., in the direction of the Spean valley。

(7). In the Spean valley itself there are at least a dozen places where the rocks by the marks on them distinctly show severe pressure and friction by some body passing over them in a S.E. direction.*

(8) Reference having been made to terraces or banks of detritus on the slopes of the hills to the south of Loch Treig, up to a height of about 1400 feet above the sea, it is proper to mention that similar banks of detritus occur on the hills to the north, and at about much the same level.

On Chlinaig Hill (before referred to) there are two such banks at a height above the sea of 1253 feet and 1373 feet.

The hill on the opposite or east side of this valley shows similar banks, and along which I walked at rather a lower level.

It appeared to me that these had very probably been formed when the land was submerged. They are essentially different from the old lake beaches, in respect of their want of horizontality.

(9) Lastly, I refer to the fact, that almost at the very tops of the highest adjoining hills great boulders are found, and in such positions as to show that they could not have come there except by floating ice. Thus, Darwin refers to the boulders on the top of hills in Lochaber, at the heights of 1700 and 2200 feet above sealevel. On the tops of two hills adjoining Loch Laggan, exceeding 3000 feet above the sea, I was informed by Sir John Ramsden of Ardverikie, the proprietor of these hills, that there are several large granite boulders.

Whilst expressing my own opinion that the kaims and boulders in the valley near the junction of the Rivers Spean and Treig indicate the agency of the sea, it is proper to advert to the opinion of my geological friend, Mr Jamieson of Ellon, that these are the moraines of a glacier which, generated in Glen Trieg, advanced into and crossed the Spean valley.

Mr Jamieson adopted the view originally suggested by Agassiz, that the barriers of all the old Lochaber lakes consisted of ice. It being necessary to find a barrier for the Glen Roy Lake not only

* These places are named in the "Memoir on Parellel Roads," by Professor Prestwick and me respectively. 
at the foot of the glen, but at the head of Glen Glaster, Mr Jamieson saw that the only way of obtaining an ice barrier at this last-mentioned place was to assume the existence of a glacier in Glen Treig, which he supposed would descend into and cross the valley, then rise up on the opposite side of the valley near the Rough Burn, and next make a nearly right-angled wheel towards Glen Glaster, dis tant from Loch Treig no less than 6 miles !

I am afraid that I must agree with Professor Prestwick (Phil. Trans. of Royal Society of London for 1879, p. 668) in the opinion he has expressed, that the "Glen Treig glacier would be incompetent to the task assigned to it" by Mr Jamieson. Professor Prestwick observes, that to block Glen Glaster col the "glacier would have to cross Glen Spean, and after that travel 2 miles with a rise of not less than 500 feet."

I agree with the Professar (page 684), that if there was a glacier from Glen Treig, which protruded into the valley, it would, instead of ascending the slopes on the opposite or east side of the valley, have followed the natural levels of the valley, and flowed down towards the north-west.

Whilst Mr Jamieson's primary object in suggesting a Glen Treig glacier was to find a barrier for the head of Glen Glaster, he also availed himself of the servioss of this glacier far explaining the origin of the kaims and boulders, which form the subject of the present paper.

One fatal objection to this view, as it appears to me, is, that the materials composing these kaims are not such as characterise moraines. They are what Macculloch properly calls "rounded. alluvium, formed by the action of water; whereas the materials of moraines being merely the débris af rocks, which fall on the surface of the glacier by meteoric agency, are totally different in character.

Another objection to this view is, that the lines of kaims in the valley lie to the south of the march which any glacier from Loch Treig would take. To meet this obvious difficulty, $\mathrm{Mr}$ Jamieson says that "the glacier on issuing from the narrow gorge at the end of Looh Treig dilated immensely;" so that its right flank might carry materials to the position occupied by the kaims and boulders. I think that if the glacier underwent such an immense 
dilatation, it would fall to pieces altogether in the valley, before it could reach the position of the kaims.

At the same time, I am far from denying that Mr Jamieson had good grounds for supposing that a small glacier existed in Glen Treig, and that it even prabably pratruded a little way into the valley.

In his map he indicates glacial strix at a point where they may have been caused by a glacier from Loch Treig. I saw these striæ, (Notes, vol. i. p. 8), viz., on masses of rock which had been smoothed and partially striated from the westward. Most of the rock was covered and concealed by detritus, which, on being cleared away by me, showed the smoathed surface of the rock. The explanation which occurred to me at the time was, that after these rocks had been so smoothed and striated the country became submerged, and the whole valley was filled with submarine beds of gravel, sand, and boulders. The spot now referred to is near that marked "Fersit" on the one-inch Ordnance Map (Sketch Map, Plate XE.).

Whilst offering my opinion, that these kaims in Spean valley are submarine detritus, and have been scoured out into long banks by the action of sea currents, I acknowledge that they deserve much mere examination than I had the opportunity of giving; and $I$ trust others who are interested in these researches will visit the locality, and publish the results of their inspection.

\section{HARRIS.}

In the Fifth Report (page 23) of the Boulder Committee it is mentioned that "at Borve, on the west coast of Harris, about half. way between Rodel and Tarbert, there is a remarkable accumulation of boulders on the side of the hill sloping down to the sea. The general slope of the hill (which reaches a height of 800 feet) is towards W. by N. (magnetic). The rocks are of gneiss, and present a series of bedis, layers, or benches more or less horizontal, forming as it were a gigantic staircase along the hill face, for about half a mile, all more or less covered by boulders. These benches of rock, in many places, show that they have been rounded by severe pressure from W. by $\mathrm{N}$. Many of the boulders which lie on them also give evidence of transport from the west." 
Two figures are appended to the Committee's Fifth Report, to illustrate these facts.

But I happen to have in my possession a more graphic representation of the locality, which I now exhibit to the Society. It was made, at my request, by a London landscape-painter, who was taking views at Harris, and whose acquaintance I happened to make, by residing in the same inn with him. He and I on one occasion travelled together in the same conveyance, and had to bait our horse at Borve, near which the hill occurs. He saw me vainly endeavouring to make in my sketch-book a drawing of the hill; and, at my request, he was so kind as to give a representation of the place in my sketch-book, which I now reproduce (Plate XIII. fig. 2). It shows how numerous the boulders are on the hill-slope, and that they had found lodgment on the ledges af gneiss racks which protrude from the hill.

I give also a representation of one of the boulders (Plate XIII. fig. 3), firmly lodged on the projecting strata of the hill ; its east end abutting against the strata in such a way as to show that it had probably come from the westward.

The interest of the locality arises from the circumstance that the hill on which those boulders lie slopes down in a westerly direction to the Atlantic Ocean; so that if the boulders on the hill came from the westward, as I think they did, they must have been transported from some land bordering on the Atlantic.

\section{EXPLANATION OF PLATES.}

\section{Plate XI.}

A sketch map reduced from Ordnance Survey, to show part of Glen Spean valley, with lines of kaims and boulders.

\section{Puate XII.}

(1). Map of smoothed granite rock in Glen Spean valley, $A B$, running in S.W. direction, and having its smoothed side fronting N.W., with a boulder pressing against it. 
Loch Treig bears W.S.W. from the rock; whilst lower part of Spean valley bears N.W. by W. from the rock.

If boulder came from Loch Treig it would not have been intercepted by the rack, but have passed on to left, viz., in a N.E. direction.

If boulder came up Spean valley it might have been, and most probably would be, obstrueted in its farther progress by the rock.

(2). Boulder A rests by one of its corners $\mathrm{C}$ on boulder B. A line drawn through centre of $A$ and corner $C$ points S.E. by S., implying transpart from N.W. by N. If boulder $A$ had come from Loch Treig it could not have stuck on boulder $B$, but have fallen off to one side.

(3). Two boulders resting on north side of a gravel bank in Spean valley. If these boulders had come from Loch Treig they probably could not have stuck there.

(4). Two large boulders in Spean valley, situated S.E. of Loch Treig. Boulder A leans against boulder B in such a way as to show that it came from the north, and not from Looh Treig. Moreover, a hill on santh side of mouth of Loch Treig is so bigh that it would have prevented these boulders reaching positions they occupy.

(5) and (6). Boulders at north side of a gravel bank in Spean valley.

\section{Plate XIII.}

(1). Is intended to represent a small portion of two kaims with boulders on their sides, facing the north. The most northern shows an interruption at $A$, as if it had been broken through by some agent from the north.

(2). Represents a hill near Barve (in Harris) sloping down to the sea-shore, covered with boulders, apparently brought from a sea-ward direction, viz., the west.

(3). Is one of many boulders on Borve Hill, resting on the rocks in suoh a way as to show transport from a westerly point. 